\section{THE ELECTION OF A DIRECT REPRESEN- TATIVE TO THE GENERAL MEDICAL COUNCIL.}

THE following are the election addresses of Sir Victor Horsley and of Mr. Joseph Smith :-

\section{SIR VICTOR HORSLEY'S ADDRESS.}

\section{To the Registered Medicat Practitioners of} ENGLAND AND WALES.

LADIES AND GENTLEMEN, -On the eve of the expiration of my term of office as one of your representatives on the General Medical Council I beg to offer myself for re-election.

After my first attendance at the Council I instituted a system of reporting to you at intervals the transaction of business in the Council.

I need not, therefore, again recount the work accomplished during the past five years, but I may justly congratulate you on an improvement in the attitude of the Council towards the profession, and in its recognition, if tardy, that reform and amendment of the Medical Acts is a pressing necessity.

My object in standing for re-election as a member of the Council is to further as much as I can the progress of those legislative changes which are not only under present social conditions essential to the welfare of the practitioner, but are, in fact, also necessary to provide adequately for the work of the Council itself and to render its educational decisions properly effective.

I am obliged to you for the confidence you have reposed in me and will endeavour if you re-elect me to fulfil as far as possible what I conceive to be the duties of your representative.

Cavendish-square, W., Sept. 7th.

VICTOR HORSLEY.

\section{MR. J. SMITH'S ADDRESS.}

To the Medical Practitioners of England and WALES.

LADIES AND GENTLEMEN,-On several occasions during the past six months I have been asked whether I would allow myself to be nominated as a candidate for the seat on the General Medical Council which shortly becomes vacant. I hesitated to give consent as I fully anticipated that some well-known general practitioner in the north of England would have been nominated in order to assert the principle of "Topographical Representation," of which so much was heard during the election last year when Dr. Woodcock of Manchester was a candidate. In that case I should have stood aside altogether.

Within the last few days several of my colleagues on the Central Council of the Incorporated Medical Practitioners' Association have urged it upon me as a duty to offer myself as a candidate in order to give general practitioners an opportunity of declaring by their votes whether they are desirous that the seats given to the profession by Parliament, in response to the oft-repeated appeals of general practitioners, should, like those granted to the corporations and universities, be handed over to consultants. When the privilege of voting for members of the General Medical Council was first granted to us in 1886 the late Sir Andrew Clark, in a letter published in the medical journals, said that the interests of consultants were already more than adequately repcesented and that it was natural and proper that general practitioners "should elect as their representatives genuine working members of their own body." If, he added, this principle of election be disregarded, "it would seem, at least to me, that the fight bad been fought and the battle won in vain."

Fellow Practitioners, to support and, if possible with your help once for all to establish, the principle so forcibly laid down by the late Sir Andrew Clark, and, I may add, subsequently endorsed by Sir Victor Horsley and other eminent consultants, I have consented to be nominated. of the 31 members of the Council there were only three general practitioners-viz., Messrs. Brown and Jackson for
England and Dr. Bruce for Scotland. How much longer is this one-sided representation to exist?

With regard to my views on medical politics generally I am in entire agreement with my friends and colleagues on the Central Council of the Incorporated Medical Practitioners' Association, Messrs. George Brown and George Jackson (your present representatives on the General Medical Council), and if you do me the honour of electing me as your representative it will be my constant endeavour to work in harmony with them. The voting papers will be issued in a few days and $I$ regret very much that the short time which will elapse before you will be called upon to record your votes prevents me from placing my views through the post more fully before each elector. I trust, however, that the cause I represent, that of the general practitioner, will be sufficient to induce every medical practitioner who reads this address to use his utmost endeavours to secure my return at the head of the poll.

I remain, ladies and gentlemen,

Your obedient servant,

Joseph SMith, M.R. C.S. Eng., L.M., L.S.A. Lond., D.P.H. Cantab.,

Late President of the Incorporated Medical Practitioners' Association, President of the Society of Members of the Royal College of Surgeons of England, \&c.

Bedford Park, Chiswick, Sept. 4th, 1902.

\section{ASYLUM REPORTS.}

Hertfordshire County Asylum (Annual Report for 1901). The average number of patients resident during the year was 528, comprising 229 males and 299 females. The admissions during the year amounted to 125, of which number 74 were males and 51 females. Of these 124 were first admissions. Dr. A. Norman Boycott, the medical superintendent, states in his report that in oriy 42 cases among the patients admitted was the insanity the first attack and of less than three months' average duration, and that in 57 cases the average duration of insanity on admission was over 12 months. "These facts, together with the advanced age of many of the patients, show that the type of insanity of the new cases was not very favourable as regards recovery." Among the admissions were 11 patients over 70 years of age. The number of patients discharged as recovered during the year amounted to 17 , or 3.2 per cent. of the average number resident. The deaths during the year amounted to 33-viz., 20 males and 13 fermales, or 6.02 per cent., as calculated on the same basis. The average age of the patients at death was 58.4 years. Of the deaths two were due to senile decay, three each to bronchitis and Bright's disease, four each to colitis and organic brain disease, five each to pulmonary tuberculosis and general paralysis of the insane, and the rest to other causes. No deaths were due to accident or violence and no inquests were held. Post-mortem examinations were made in 31 cases. The general health of the institution has been satisfactory. During August and September there was an outbreak of colitis chiefly affecting old and feeble patients. No other disease of an infectious nature has occurred. Owing to the epidemic of small-pox in London and also to the occurrence of cases in the neighbourhood of the asylum it was considered necessary in November to stop the visiting of patients by their friends. There have been no serious casualties during the year. The Commissioners in Lunacy state in their report that the wards were bright, clean, and cheerful; that the dormitories were fresh and clean; that the patients were neatly dressed and orderly in behaviour; and that the medical case-books were intelligently and well kept. The committee of management states in its report that the main asylum buildings were completed during the year and that the wards were now occupied throughout the institution. An application was made to the Local Government Board for a. loan of $£ 2000$ for the carrying out of the painting and papering of the asylum. The heating and lighting arrangements have worked well. A scheme for the disposal of the sewage has been prepared and application made to the Local Government Board for a loan of $£ 2450$ to carry out the said scheme. The maintenance rate for patients per week was 14s. per head. 